\title{
GABRIEL MARCEL I PERSPEKTYWY FILOZOFII RELIGII
}

Banałem jest powiedzieć, że to nie filozofowie wprowadzili Boga do filozofii; ani znane zdanie na ten temat E. Gilsona, ani podstawowe twierdzenie filozofii Boga H. Duméry'ego nie są tu szczególnie odkrywcze. Swiadczą o tym po prostu dzieje starszych od filozofii różnych religii zarówno jak dzieje samej filozofii, w której ojcowie naszego dziedzictwa: Anaksymander czy Parmenides, pierwsi filozofujący teologowie jawią się z niezatartym piętnem swych religijnych korzeni. Czyż trzeba przypominać, że utożsamienie Pierwszej przyczyny z Bogiem u św. Tomasza dokonuje się przez odwołanie do tradycji religijnej „Tego, którego wszyscy zwą Bogiem"? Jeśli cywilizacja zachodnia przeżywa wciąż jeszcze „śmierć Boga”, to nie znaczy, że przeżywa śmierć szczególnej filozofii Boga, np. ontoteologii, lecz że religia przestała — przynajmniej na pozór — określać życie tej cywilizacji. Dlatego marzenia niektórych teologów, że po odrzuceniu metafizyki, odnajdzie się na powrót Boga religii, wydają się z gruntu naiwne: albo Bóg przenika życie ludzkie z wnętrza najszerzej rozumianej religii, albo istotnie umiera w sercach i umysłach ludzi.

Czy fakt ten jednak ma jakieś znaczenie dla filozofii? Czy stanowi dla niej jakieś wyzwanie, czy też, przeciwnie, alibi pozwalające jej parać się spokojnie matafizyką racjonalną, jakby nigdy nic, pod pretekstem, że nie do niej należy wprowadzenie na powrót Boga w życie ludzkie? Otóż wydaje się, że fakt ten co najmniej może dla filozofii Boga mieć zasadnicze znaczenie. Nie powinno być bowiem dla niej obojętne, w jakiej sferze życia ludzkiego Bóg się w ogóle ujawnia, jaki jest Jego pierwotny i najgłębszy sens, którego jedynie pochodną, być może, jest sens, jaki uzyskuje On w metafizyce. Jeśli filozofem Boga jest np. chrześcijanin, nie powinno mu być chyba także obojętne, czy swoim filozofowaniem pomaga, czy nie, w usuwaniu zapór leżących na drodze doświadczenia Boga w naszych czasach, także w naszym własnym religijnym, ale o słabym stopniu wiedzy religijnej, kraju. Jednakże zwrócenie się ku fenomenom religijnym w poszukiwaniu podstaw filozofii Boga może prowadzić do konieczności rewizji sposobu filozofowania w ogóle. Poszukując podstaw rzetelnej fi l o zo fii religii trzeba może odważyć się wesprzeć - choć niekoniecznie bezkry- 
tycznie - o nową filoz ofię religi n ą. Filozofia religii to nie to samo co filozofia religijna: o ile ta pierwsza zajmuje się wyłącznie ogromnym wachlarzem ludzkich odniesień do Transcendencji i ich intelektualną artykulacją, o tyle ta druga buduje dla religii — w sposób niekoniecznie intencyjny — podstawy w łonie całościowej koncepcji rzeczywistości. Filozofia religii tylko wtedy nie jest zawieszona w próżni, jeżeli ma do dyspozycji jakieś „gościnne struktury" ogólnofilozoficzne, ukazujące możliwość i pierwotność religijnego właśnie, to jest całościowego, a nie tylko intelektualnego stosunku do boskiej Transcendencji.

Co ma dzisiejszemu światu do zaoferowania filozofia Gabriela Marcela? Jakie otwiera perspektywy na filozofię religii? Jakie zawiera znaki zapytania? W pierwszej części tej wypowiedzi zajmę się niektórymi założeniami ogólnofilozoficznymi myśli Marcela w stopniu, w jakim otwiera się ona na wymiar religijny. W części drugiej pokażę konsekwencje tych założeń dla Marcelowskiej filozofii wiary. W części trzeciej wskażę natomiast na niektóre kłopoty tej filozofii i znaki zapytania, jakie przed filozofią stawia.

\section{PARTYCYPACJA I TAJEMNICA}

Centralną w pewnym sensie ideą Marcela jest idea partycypacji w jego własnym rozumieniu. Powstała ona na gruzach innej, heglowskiej idei wiedzy absolutnej, którą Marcel poddał ostrej krytyce u zarania swojej filozofii. W oczach Marcela idea wiedzy absolutnej prowadzi do nieuchronnych sprzeczności, czyniąc z jednej strony z Absolutu sumę zniesionych i zarazem zachowanych skończoności, wessanych w gigantyczną machinę samotworzenia Absolutu, a z Prawdy sumę cząstkowych nieprawd, z drugiej zapominając, że wszelka wiedza, którą możemy sensownie pomyśleć, odniesiona jest do aktu skończonej myśli, od którego nie może zostać arbitralnie oderwana. Inaczej mówiąc bezsensowna jest koncepcja totalnego s y s t e mu wiedzy jako pewnej rzeczywistości: system taki, względem którego nic nie byłoby zewnętrzne, niszczyłby zarówno niepowtarzalność skończonego myślącego podmiotu, jak absolutność samego Absolutu. W takim razie trzeba móc pomyśleć relację myśli i rzeczywistości, bytu, której nie groziłoby zesztywnienie w system. Relacją taką jest wzajemna partycypacja myśli i bytu — czy lepiej powiedzieć po heideggerowsku - bycia; wzajemna, gdyż zarówno skończona myśl jest nie do pomyślenia bez odniesienia do bycia, jak bycie — by nie zamieniać go w niepoznawalną hipostazę intelektu - musi być rozumiane właśnie jako to, w czym myśl skończona uczestniczy, czyli jako do tej myśli odniesione. Pierwotna nie jest więc bynajmniej ani obiektywna koegzystencja rzeczy, ani odniesienie podmiotu do przedmiotu, lecz dynamiczne wzajemne uczestnictwo najszerzej rozumianego skończonego myślenia i czegoś takiego jak „bycie”. 
Istotne dla myśli Marcela jest to, że podmiot partycypacji jest ludzkim k o n k retem, a nie abstrakcyjnym podmiotem myślenia i że partycypacja da się rozumieć tylko w konkretnych modi, które ze swej strony dookreślają to w czym podmiot uczestniczy. Czy jest nim po prostu owo bycie? Z punktu widzenia Marcela mniejsza o nazwę, partycypacja bowiem ma charakter dynamiczny i — użyjmy tu tego terminu — analogiczny, jej sens jest także z całą pewnością metafizyczny, to znaczy, że dotyczy ona tego co podstawowe i ostateczne. We wszystkich jednak analizach różnych poziomów partycypacji mamy u Marcela do czynienia z wglądem w szczególną j e d n o ść rzeczywistości, która nie jest ani tożsamością, ani relacją zakładającą niezależne od niej substancjalne terminy i która nie może być w ogóle rozumiana w sensie obiektywistycznym. Myślenie obiektywistyczne wyłania się z partycypacji jako swego rodzaju ambiwalentna odrośl - dotkniemy na końcu tego zagadnienia.

Rozpatrzmy krótko podstawowe modi partycypacji, które rozwarstwiają równocześnie Marcelowską metafizykę. Najpierw egzystencja, która jest uczestnictwem poprzez cielesność w is t $n$ i e n i u obecnym jako dana w odczuwaniu podstawowa pewność „w nierozłącznej jedności istnienia i tego co istnieje" (JM, 313)1 , a zarazem jedności ze światem, od którego nie oddziela podmiotu żadna bariera: ,przylegam rzeczywiście do wszystkiego co istnieje - do świata, który jest mój i którego moje ciało jest centrum" (JM, 265). Myśl nie może nigdy wyswobodzić się z istnienia, co przekreśla jednocześnie pretensje idealizmu transcendentalnego i tych, którzy chcieliby istnienie w jakimkolwiek sensie dowodzić: istnienie ,albo jest pierwsze, albo go nie ma, ale nie może w żadnym wypadku być traktowane jako redukowalne, jako pochodne" (JM, 314). Oto dlaczego nie ma sensu tzw. pierwsze pytanie metafizyki ,jak to się dzieje, że coś istnieje, że ma istnienie”, ponieważ „zakłada ono możliwość, która nie jest nam dana, wyabstrahowania się w pewien sposób z istnienia, umieszczenia się na zewnątrz niego by go oglądać" (EPR, 21). Nie znaczy to, że istnienie jest czymś os ta tecznym, ale że jest czymś podstawow ym, od czego tu na ziemi nie ma ucieczki. Ucieczki, istnieć bowiem to równocześnie „prowadzić w czasie rozpaczliwą walkę” (PI, 147), „czuć się uwięzionym” (PI,

${ }^{1}$ W tekście artykułu stosuję następujące skróty tytułów prac G. Marcela (liczba po skrócie oznacza stronę):

JM - Journal métaphysique, Paris 1927.

EA - Etre et avoire, Paris 1935.

EPR - Entretiens avec Paul Ricoeur, Paris 1968.

HV - Homo viator, Paris 1944.

IT - I and Thou, [w:] The Philosophy of Martin Buber, La Salle III. 1967, s. 41 - 48.

ME II - Le mystère de l'être, t. 2, Paris 1951.

PA - Position et approches concretes du mystère ontologique (dodatek do dramatu: Le monde cassé), Paris 1933.

PI - Présence et immortalité, Paris 1959.

PST - Pour une sagesse tragique et son au-dela, Paris 1968.

RI - Du refus à l'invocation, Paris 1940.

TE - Le témoignage comme localisation de l'existentiel, „La Nouvelle Revue Théologique” 68:1946 s. $182-191$. 
139), a także tkwić w nieprzejrzystości: wcielona świadomość nie jest „świetlistym kręgiem, poza którym rozciągają się dla niej tylko ciemności. Przeciwnie, ciemność jest właśnie w samym środku" $(E A, 15)$.

Dlaczego? Cielesność bowiem, jako mo j a , jest równocześnie w tajemnej zmowie z pierwotnym ruchem naszej wolności, zamykającym nas w naszym ja, które jest „zacieśnieniem, sklerozą” i rodzącym sposób egzystowania zwanym przez Marcela „posiadaniem”. Posiadanie - to postawa odpowiedzialna za zewnętrzność i izolację: oddzielamy się od innych i zarazem uzależniamy od tego co poza nami, by to posiąść. W tym celu określamy „przedmioty”, przeliczamy, budujemy systemy, lecz w końcu wpadamy w rozpacz: to, co da się określić jest także tym, co da się wyczerpać - spoza przedmiotów wyziera nicość, przeliczany czas staje się za krótki, rodzi się pokusa nihilizmu.

Wówczas - twierdzi Marcel — budz̊ się w nas pragnienie „aby wszystko nie sprowadzało się do gry pozorów, następujących po sobie i niespójnych (...) lub do historii opowiedzianej przez idiotę, by podjąć wyrażenie Szekspira" (PA, 261). To pragnienie prawdziwości jest równocześnie pragnieniem by ci a, którego to pragnienia samo istnienie nie wypełnia. Być, to nie to samo, co istnieć, to także nie to samo co żyć. Ale co to znaczy „być”?

W tym punkcie budowanie przez Marcela „struktur gościnnych dla religii” osiąga pod pewnym względem swoją dojrzałość. Pytanie o bycie wtrąca najpierw Marcela w namysł nad samym sposobem postawienia tego pytanie: jeśli pytam co to znaczy „być”, to czyż mogę wyłączać siebie samego z tego pytania? Z kolei jednak czyż mogę być pewnym, że ja który pytam o bycie sam jes t e m? Otóż tak długo mogę próbować myśleć, że odpowiedź na to pytanie jest odpowiedzią mo ją — jak sąd podmiotu na temat jakiegoś przedmiotu — póki nie spostrzegę, że dążę do „afirmacji, którą raczej jestem, niż ją wypowiadam" (PA, 266); inaczej mówiąc, że „być” jest ode mnie bardziej pierwotne, wcześniejsze niż wszelkie zapytywanie i intymniejsze niż wszelki przedmiot myśli. Lecz przecież zarazem to „być” jest upragnione, jest korelatem „wymogu ontologicznego" i między moją egzystencją a moim byciem rozwiera się dystans, który definiuje moje życie: mogę wszak moją egzystencję oceniać w imię tego, czym powinienem b y ć. Sytuację tę określa Marcel mianem „tajemnicy ontologicznej".

Tajemnica to „sfera, w której rozróżnienie tego, co jest we mnie i tego, co jest przede mną traci swoje znaczenie i swój pierwotny walor" (EA, 169). Bycie nie jest $n$ a zewnątrz mnie, nie mogę zatem uczynić $\mathrm{z}$ niego „problemu bycia", a więc pewnego przedmiotu myśli, podatnego na charakteryzację. Bycie jest zbyt blisko, by był tu możliwy dystans, w byciu od początku uczestniczymy - oto najgłębsza intuicja teorii partycypacji. Ale równocześnie bycie to system perspektyw, w których ograniczone dane naszego świata nabierają znaczenia całkowicie odnowionego, to punkt odniesienia naszych pragnień, a zarazem miara naszych osądów rzeczywistości. Nie tym samym więc jest bycie 
jako to, co „hypoproblematyczne”, o które w gruncie rzeczy, podobnie jak o istnienie, nie mogę pytać, „ponieważ możemy pytać jedynie wychodząc z bycia” (PST, 82) - i bycie jako to, co „hyperproblematyczne”, to znaczy jako pełn i a, „pleroma”. Przeciwnieństwo pełni i pustki wydaje się Marcelowi ważniejsze niż przeciwieństwo jedności i wielości i zakorzenia w doświadczeniu. $\mathrm{W}$ tej perspektywie „bycie jest wtedy, gdy nasze wyczekiwanie jest spełnione - mówię o tym wyczekiwaniu, w którym uczestniczymy całym sobą" (JM, 202); albo: „bycie jest tym, co nie zawodzi” (JM, 177). Lecz choć ostatecznie „nie ma bycia jak tylko w wieczności” (JM, 151), to owa pełnia nie jest całkowicie poza doświadczeniem, jest w pewien sposób obecna w głębi takich fenomenów jak wierność, nadzieja czy miłość, jako „rzeczywistość, która mnie przekracza i obejmuje, przy czym jednak w żaden sposób nie mogę jej traktować jako to, co zewnętrzne wobec tego, czym jestem" (RI, 188).

Dwie jeszcze sprawy wymagają tu krótkiego dopowiedzenia. Po pierwsze tajemnica ontologiczna jest korelatem ludzkiej wolności w tym przynajmniej sensie, że można ją, lub nie, rozpoznać: „z samego faktu, że do istoty tajemnicy należy bycie rozpoznaną, czy też to, że ma być rozpoznana, wynika także, że może być zapoznana i czynnie negowana" (EA, 170).

Po drugie uprzywilejowanym miejscem rozpoznania tajemnicy jest skupienie. Skupienie jest szczególnym fenomenem, o którym trzeba powiedzieć dwie znów rzeczy: (1) „nie polega ono na oglądaniu czegokolwiek, (lecz) jest ożywieniem, przebudową wewnętrzną" (PA, 274); skupienie to zatem nie oglądanie, lecz jakby ruch wewnętrzny, konwersja; (2) w skupieniu dokonuje się rozluźnienie wewnętrzne i jakby powi e r z e n i e się: „powierzenie się wobec rozprężenie się w obecności — choć w żaden sposób nie mogę dołączyć do tych przyimków rzeczownika, który by nim rządził. Myśl zatrzymuje się na progu" (PA, 273).

Zanim przejdziemy do trzeciego modusu partycypacji, spójrzmy wstecz na przebytą drogę. O co chodzi Marcelowi w jego idei tajemnicy ontologicznej oraz w jego koncepcji istnienia? O rozpoznanie takiego wymiaru rzeczywistości, w którym nie ma miejsca na relację podmiot—przedmiot, ponieważ jest on zbyt bliski, zbyt intymny, a zarazem zbyt bogaty — ma głębię, której nie da się wyczerpać. Tajemnicy ontologicznej nie da się zatem scharakteryzować przy pomocy pojęć jasnych i wyraźnych, można natomiast ją oświetlić poprzez refleksję filozoficzną, która ukazuje jej obecność w różnych, najzupełniej konkretnych sytuacjach życiowych. Obecność czego dokładnie? Sfery, w której staje się możliwe przechodzenie $\mathrm{z}$ wymiaru naszych dramatów egzystencjalnych w wymiar transcendentny, jako taki najczęściej nie uświadamiany, lecz do którego przystęp jest niemożliwy bez określonego użytku naszej wolności: przed głębią bycia można się zawsze zamknąć lub otworzyć.

Lecz zwroty „powierzenie się wobec” i „rozprężenie się w obecności” sugerują jeszcze inny, najbardziej podstawowy modus partycypacji: intersu- 
bi e k t y w n ość. To, co Marcel nazywa „węzłem intersubiektywnym”, jest tak blisko wymiaru bycia, jak to możliwe: „troszczę się o bycie jedynie w stopniu, w jakim uświadamiam sobie mniej lub bardziej ukrytą jedność, która łączy mnie z innymi istotami, których rzeczywistość przeczuwam" (ME II, 20), dlatego „myśl, która kieruje się w stronę bycia, odtwarza tym samym intersubiektywną obecność" (ME II, 19). Jedność, więź — oto kluczowe terminy równocześnie Marcelowskiej ontologii, antropologii i filozofii religii. Jedność, o którą tu chodzi, jest in t y m ną wi į zi ą, której najgłębszym spoiwem jest miłość. Lecz także ta więź ma dwa poziomy: jeden, poniżej poziomu refleksji, warunek możliwości wszelkiego rozumienia, wszelkiej komunikacji, „tajemniczy korzeń języka” (ME II, 14), który ,,jest niedopowiedziany i pozostaje niedopowiedziany, nawet gdy usiłuję kierować nań moją myśl” (ME II, 18). Drugi jest najgłębszym s e n s e m naszego pragnienia ontologicznego, a zarazem naszych obcowań z jakimiś „ty”, w których uwikłana jest zawsze także nasza wolność. $\mathrm{Z}$ innymi podmiotami możliwa jest bowiem albo obojętna relacja „triadyczna”, w której drugi jest jedynie źródłem pewnych komunikatów, bądź wręcz obcym „on”, albo relacja „diadyczna” ja-ty, która tworzy i domaga się jedności tak głębokiej, iż „my” wydaje się głębsze, niż ja i ty wzięte osobno. Owo „my” jest „współbyciem”, co-esse, które wyznacza najgłębszy sens „esse” jako takiego: esse w swym rdzeniu jest właśnie co-esse, którego intymność istnienia jest jedynie prefiguracją. Lecz współbycie jakże jest kruche, jakże zagrożone wciąż powracającą samotnością, niezrozumieniem, obcością, śmiercią. Oto dlaczego całym sercem pragniemy co-esse niezniszczalnego - Marcel mówi tu o doskonałej orkiestrze, gdzie „ci, których nazywamy nieprzystojnie umarłymi są bez wątpienia o wiele bliżej Tego, o którym nie należałoby może mówić, że prowadzi symfonię, ale który je s t symfonią w jej głębokiej i rozumnej jedności” (ME II, 188).

Dopowiedzmy tu więc od razu to, co kluczowe: relacja ja—ty wikła w sobie ideę Absolutnego Ty, który nie mógłby nigdy stać się „on”, który byłby samą bliskością i intymnością, to znaczy doskonałym wypełnieniem intersubiektywności, a zarazem jej najgłębszym fundamentem: „Czyż nie trzeba [...] powiedzieć, że Ty jesteś w pewien sposób gwarantem tej jedności, która nas łączy, mnie ze sobą samym, lub jednego człowieka z drugimi [...] I więcej nawet niż gwarantem, który by z zewnątrz upewniał czy umacniał już uformowaną jedność — jesteś samym cementem, który ją spaja” (HV, 83).

\section{MARCELOWSKA FILOZOFIA WIARY}

Jakie perspektywy metafizyka Marcela otwiera na filozofię religii i Boga? Myśl Marcela jest całą sobą — by tak rzec — otwarta na wymiar transcendentny. Lecz w myśli tej nie jest ani możliwe ani potrzebne dow o d ze ni e czego- 
kolwiek. Dowód istnienia Boga jest niemożliwy z dwóch zasadniczych powodów: (1) Nie możemy wyswobodzić się $\mathrm{z}$ istnienia i stanąć jakby na zewnątrz niego, by wprowadzić tu kategorię przyczynowości: „Problem genezy mnie i genezy świata jest jednym i tym samym problemem, a raczej jednym i tym samym insolubile i ta nierozwiązywalność jest złączona $\mathrm{z}$ samą moją pozycją, $\mathrm{z}$ moim istnieniem, $\mathrm{z}$ radykalnym faktem metafizycznym tego istnienia" (EA, 23 - 24). (2) Bóg nie może być w żadnym sensie prze d mio te m dowodzenia: „to, czego istnienie mogłoby być udowodnione, nie byłoby, nie mogłoby być Bogiem" (JM, 223). Lecz ponadto sama idea dowodu wydaje się Marcelowi w tej dziedzinie podejrzana, wikła bowiem sytuację intersubiektywną, która zakłada albo wspólnotę wartości - a więc ostatecznie w i a r ę w Najwyższe Dobro - między „mistrzem” a „uczniem”, a wówczas dowód jest niepotrzebny, albo też możliwość zmiany obrazu aksjologicznego rzeczywistości przez ciąg rozumowań, który jednak musi pozostawić nietkniętą decyzję wolności. Dlaczego? Ponieważ Bóg jest nade wszystko ni e o b o jęt n y, jest Świętością, nieobecną poza pokorną adoracją, oraz Ty Absolutnym, o którym myśleć to nade wszystko modlić się do Niego. Otóż zarówno adoracja, jak modlitwa zakładają wiar ę. Marcelowska filozofia religijna - to nade wszystko filozofia wiary.

Czym jest wiara u Marcela? Z pewnością nie jest ani opinią, ani przekonaniem, ani hipotezą: opinia ma charakter bezosobisty i polemiczny, przekonanie jest raczej sztywnym rynsztunkiem intelektualnym, niż osobistym zaangażowaniem, hipoteza zakłada możliwość — wykluczającą się z wiarą — weryfikacji lub falsyfikacji. Czym więc wiara jest?

Najpierw szczególnym przylgnięciem, afirmacją tego, co przekracza wszelką charakteryzację, co transcendentne epistemologicznie względem wszelkich intelektualnych dystynkcji, ale co dlatego nie da się uszczegółowić. „Powiedzą mi w istocie: o j a k i m wierzeniu pan mówi? o j a k i e j wierze? Tutaj znowu będzie się ode mnie żądało wyszczególnień: jeżeli odmówię, zarzuci mi się pozostawanie w nieokreśloności takiej, że wszelka dyskusja, ale także wszelkie wyjaśnienie jest niemożliwe. A jednak trzeba zachować tę wiarę całościową, jednolitą, jako poprzedzającą wszelkie możliwe wyjaśnienia: zakłada ona przywarcie do rzeczywistości, której właściwością jest nie podzielność i nieprzeliczalność. To przywarcie byłoby niemożliwe, gdyby owa rzeczywistość nie była dla mnie obecna, a może należałoby powiedzieć: g d y b y mi e całego nie otaczała" (EA, 177 - 179). Jak widać z tego cytatu, wiara u Marcela jest pierwotnie sposobem, w jaki otwieramy się na tajemnicę ontologiczną jako taką, na otaczającą nas, lecz najczęściej przez nas przeoczaną głębię rzeczywistości, której nie da się wyczerpać. Bez takiego otwarcia wszelki przystęp do sfery religijnej sensu stricto wydaje się Marcelowi niemożliwy. To wiara, a nie rozumowania, lecz wiara najczęściej naświetlona refleksją metafizyczną, wprowadza nas w partycypację: trzeba tę partycypację jakoś doświad- 
czyć, ale doświadczenie to już zakłada gest otwarcia, rozluźnienia się i powierzenia czemuś, czego w żadnym sensie nie możemy posiąść.

Lecz wiara jest równocześnie rzeczywistością intersubiektywną, więzią z Bogiem, pierwotną religią, będącą związkiem dwóch wolności. Ten to związek tropi Marcel przede wszystkim i filozofia wiary jest nieodłączona od filozofii wolności. Prześledźmy krótko najważniejsze etapy tej filozofii.

Wczesna teoria partycypacji prowadzi wprost do filozofii wiary. Skoro wszelka wiedza jest dla skończonego podmiotu wiedzy, znaczy to, że nie jest on przez nią ograniczony, jest więc wolny. Ale cóż to byłaby za wolność, która musiałaby w świetle pojęć ogólnych uważać siebie jedynie za egzemplarz gatunku? Wolność domaga się akceptacji swojej własnej podmiotowej k onkretności - lecz żadna wiedza takiej akceptacji nie może jej dostarczyć. Wolność może być zaakceptowana tylko przez inną wolność w miłości - oto kluczowa teza Marcela. Ale akceptacja ta musi być zarazem tworzeniem dogłębnej se ns ow ności tego, co w świetle wiedzy niepojęte - czyli ostatecznie twórczym „fiat” mojego i każdego innego konkretu przez boskie Ojcostwo. Lecz o owym „fiat" nie powiadamia nas żadna wiedza, która operuje zawsze generaliami, lecz jedynie wiara, a raczej — refleksja filozoficzna nad konstytucją we wierze konkretnej wolności jako takiej.

W koncepcji tej nie da się prawomocnie oderwać rzeczywis tości Boga od wiary, gdyż - choć niemożliwa do sprawdzenia - wiara ta jest wiarą w Boga. Lecz sformułowanie Marcela z I części Dziennika metafizycznego: „duch ustanawia Boga jako ustanawiającego jego" (JM, 46) wydaje się wkrótce Marcelowi wysoce niezadowalające. Najpierw dlatego, że wcielony podmiot $\mathrm{w}$ istocie niczego nie ustanawia, lecz zanurzony od początku w istnieniu raczej zdolny jest do doświadczenia różnych, analogicznych pięter intymności, tak że Marcel może napisać iż „wiara powinna uczestniczyć w naturze wrażenia" i że mogę pojąć nieskończone możliwości widzenia itd poza granicami zwykłej czasoprzestrzeni (JM, 305). Następnie jednak odkryta niebawem idea relacji diadycznej przekształca samą koncepcję Boga: nie jest to już niepojęty w istocie warunek możliwości mojej wolności, lecz Absolutne Ty, do którego „istoty” należy, że jest dla Niego ważne, iż w Niego wierzę, w przeciwieństwie do stołu, całkowicie obojętnego wobec faktu, że o nim myślę. „Bóg, którego nie interesowałaby moja wiara, nie byłby Bogiem, lecz zwykłym jestestwem metafizycznym”, której jest „bez wątpienia najuboższą, najbardziej martwą z fikcji" (JM, 137).

Oznacza to, że prawomocnie rozumiany Bóg — Bóg religii - może być jedynie myślany $z$ wnętrza intersubiektywnej partycypacji, w której panuje wzajemne zainteresowanie się i udzielanie Boga i człowieka; Boga, który jest wolnością i dlatego może również się n i e objawić — ta możność skrycia się jest nawet pierwotnym znaczeniem Marcelowskiego terminu „tajemnica”. Tak rozumiany Bóg religii jest teoretycznie nieobalalny przez racjonalistyczną krytykę, 
gdyż każda próba Jego negacji zamienia się automatycznie w idolatrię, w traktowanie Absolutnego Ty jako monstrualnego „on”, nie trafia więc po prostu w to, co chce krytykować. Ale ceną za tę koncepcję jest zakaz bezpośredniego dyskursu o Bogu: „gdy mówimy o Bogu, wiedzmy, że nie o B og u mówimy” (JM, 158). Lecz pozostaje zawsze dyskurs pośredni i filozofia wiary. Jak usprawiedliwia ją Marcel? Usprawiedliwienie to pojawia się stopniowo wraz z pogłębieniem koncepcji wiary i centralnym dla niej pojęciem próby.

Wiara jest $\mathrm{z}$ istoty ryzykiem: pokusa nihilizmu grozi zawsze, nic nas do wiary przymusić nie może. Ukazuje to analogię między wiarą a wolą w ich stosunku do przeszkody jako takiej, którą obie biorą w pewien sposób w nawias: „sprawa, od której abstrahuje wola dotyczy wiedzy, czy dane działanie może zostać spełnione; pytanie, którego postawienia odmawia wiara brzmi: czy jest to naprawdę możliwe?" (JM, 182). Lecz to przekraczanie przeszkód uzyskuje swój najgłębszy sens jako proces, który wikła kategorię próby: „wiara jest $\mathrm{z}$ istoty czymś, co powinno i chce być wypróbowane (...) Próba jest tym, co ma swoje ponad" (JM, 198). Jeśli jednak mogę mówić o próbie wiary to z kolei dlatego, że „mogę mieć wiarę jedynie w to, czym jestem, albo raczej w to, przez co jestem. Chcę przez to powiedzieć, że wiara nie mogłaby dotyczyć porządku metafizycznego, który byłby mi radykalnie obcy" (JM, 184). Inaczej mówiąc wiara wikła pojęcie zbawienia, a przez to — na okrężnej drodze — także pojęcie bycia, gdyż „odkąd istnieję, coś jest zagrożone, ale może być zbawione i nie będzi e inaczej, jak tylko pod warunkiem zostania zbawionym" (JM, 282). Marcel przyznaje zresztą, iż „można uważać za dziwne, że utożsamiam, jak to czynię, problem bycia i problem zbawienia" (JM, 180).

W tym momencie ujawnia się szczególnie ścisły związek filozofii wiary i filozofii wolności. Czymże bowiem jest próba? Procesem edukacji wolności, która pierwotnie zazwyczaj skurczona wokół siebie zaczyna przechodząc przez próbę móc się rozluźniać i powi e r za ć, a przez to naprawdę wyzwalać. Rozluźnienie to jest wprost proporcjonalne do przechodzenia od postawy triadycznej względem rzeczywistości i Boga jako pewnego „ens rationis”, którego się uprzednio nieraz neguje i między którym a nami panuje obcość i napięcie, do postawy diadycznej, w której dochodzi do wewnętrznego uproszczenia i otwarcia kredytu. To rozluźnienie jest możliwe dlatego, że odpowiednio przeżywana próba wpuszcza swoiste świ atło, które pozwala na to, co można by nazwać ostatecznie ,życiem wiarą". Na analizie takich prób polegają w dużej mierze Marcelowskie „konkretne przystępy do tajemnicy ontologicznej”: nadziei, miłości, wierności. Oto opis aktu nadziei nieuleczalnie chorego: „Wszystko dla mnie stracone skłonny był początkowo powtarzać chory, utożsamiając naiwnie wyzdrowienie $z$ wybawieniem. Jest jednak oczywiste, że z chwilą, gdy nie tylko uzna on abstrakcyjnie, ale zrozumie do głębi czyli zo b a czy, że wszystko może nie być stracone, nawet jeśli wyzdrowienie nie nastąpi, wówczas jego postawa wewnętrzna w odniesieniu do wyzdrowienia czy nie wyzdrowienia ule- 
gnie całkowitej przemianie; zdobędzie on wolność, zdolność odprężenia" (HV, 59).

Czym jest tu dokładnie biorąc wiara? Marcel na tym etapie utożsamia ją z absolutną wiernością względem „całości bytu” (EA, 63) lub „absolutnej osoby" (EA, 139). Lecz okazuje się, że tak rozumiana wiara jest o d pow i e d zi ą: „Wszelkie zaangażowanie jest odpowiedzią" (EA, 63). Jaką odpowiedzią? I na co? Pytania te prowadzą Marcela do ostatecznego pogłębienia koncepcji wiary.

Na co odpowiedzią jest wiara? Jest odpowiedzią na w e z w a n i e, „na mgliste, milczące zaproszenie, które duszę wypełnia, albo w innym ujęciu, na wywierany na nią nacisk, ale nie przymus” (EA, 310). Jest odpowiedzią na świ atło, które jest równocześnie prawdą i darem. Zatrzymajmy się chwilę przy tym ostatnim zespole pojęć. Między wiarą a prawdą (a także tajemnicą bycia) istnieje ścisły związek i ,za każdym razem, gdy między jednym a drugim zaczyna tworzyć się dystans, jest to dowód, że albo wiara dąży do popadnięcia w idolatrię, albo że duch prawdy usycha, ustępując miejsca rozumowi mędrkującemu" (ME II, 178). Prawda emanuje ze światła, które jawi się przede wszystkim jako dar, nie zaś jako jakaś obiektywna przyczyna. Marcel widzi związek między darem, wspaniałomyślnością a światłem. „Duszą daru jest wspaniałomyślność", której światło jest niezastąpioną metaforą. W ten sposób rysuje się prawomocny ciąg wzajemnie do siebie odsyłających symboli: „światło jako to, co działa fizycznie, pomaga nam myśleć wspaniałomyślność; ale z kolei wspaniałomyślność, skoro tylko zaczynamy myśleć ją w jej istocie, daje nam w pewien sposób przystęp do światła metafizycznego, tego samego, o którym mówił św. Jan: tego które oświetla każdego człowieka przychodzącego na świat" (ME II, 122).

Wiara jest nie czym innym, jak odpowiedzią na to światło - w innym języku na „uchwycenie przez Byt” (EA, 63) — które od początku wikła ludzką woIność: „mogę zawsze powiedzieć: tak, sądziłem, że widzę, lecz się pomyliłem” (EA, 142). Jest tak dlatego, że Światła-Daru nie da się po prostu zidentyfikować, lecz „daje się ono rozpoznać jedynie przez dary, których udziela” (ME II, 144). Otóż każdy z nas jest w stanie rozpoznać, że jego istotą ,,jest dar (..), że każdy sam jest darem i że w ostatecznym rachunku w żadnej mierze nie istnieje przez siebie" (ME II, 174). Dar bycia i dar wolności: istnieje coś takiego, jak doświadczenie łaski, wówczas np. gdy stajemy się zdolni do przebaczenia, a więc do pewnej twórczości etycznej - w samym sercu mojej twórczości mogę rozpoznać, że jest ona darem. Lecz rozpoznanie to domaga się po pierwsze wewnętrznej konwersji, po drugie świadectwa, po trzecie zawierzenia.

Konwers j a polega przede wszystkim na uzdolnieniu do pokory, która jest „podstawową cnotą metafizyczną” (PST, 13), gdyż istotą pokory jest rozumny akt przyznania się ludzkiej świadomości, że ,jest zależna od kogoś innego, niż ona sama” i „pokora w ścisłym sensie zakłada pewną afirmację sacrum” 
(ME II, 86). Nawrócenie prowadzi wprost do możliwości dawania świ a de ctwa: „nawrócenie jest aktem, w który człowiek zostaje powołany, żeby stać się świadkiem” (ME II, 134). To tutaj właśnie jest miejsce na wierność, gdyż „świadectwo zakłada wierność pewnemu światłu — powiedziałbym chętnie w innym języku: pewnej otrzymanej łasce" (TE, 188). Lecz najgłębszym warunkiem świadectwa i całej wiary jest zawierzenie. Wiara bowiem - to przede wszystkim ,wiara w...", to znaczy pewien bezwarunkowy kredyt, któremu towarzyszy ruch przyłączania się, iścia za... Kredyt jest ryzykiem i dlatego wiara jest zawsze przekraczaniem tego, co dane ku Absolutnemu Ty. Lecz Absolutne Ty nie jest kimś zewnętrznym: jest bardziej wewnątrz mnie, niż ja sam i mnie kocha - oto dlaczego nie ma sensu ateizm buntu przeciwko wyimaginowanemu zewnętrznemu panu. Ale dlatego też tak ważna jest filozofia intymności i tajemnicy. Dzięki niej bowiem mogę dojrzeć równocześnie, że $\mathrm{z}$ jednej strony w gruncie rzeczy wiara ,jest moim bytem, jest naprawdę sednem tego, czym jestem" (RI, 223) i że ta fundamentalna wiara jest podstawą osądu mojej i cudzej niewiary, z drugiej, że właśnie nie wierzę, o ile przez moją niewierność „nie pozwalam ukazać się i jakby świecić przeze mnie temu światłu, na które się otwieram, gdy wierzę" (tamże). To ostatnie stwierdzenie jednak może mi nareszcie umożliwić wspólnotę z niewierzącym, której na próżno poszukiwały dowody. Mogę bowiem się przekonać, że „ten, kto oświadcza, że jest niewierzący, bardziej prawdziwie, bardziej skutecznie ode mnie, który się uważam za wierzącego, poświadcza tę rzeczywistość, jaka zawarta jest w moim akcie wiary" (RI, 234).

\section{PERSPEKTYWY I APORIE}

Gdzie leży siła filozofii Marcela, a gdzie jej słabość? Moim zdaniem siła tej filozofii polega przede wszystkim na tym, że pokazuje, iż filozofia Boga powinna być ufundowana na filozofii wiary, a więc i religii, a nie odwrotnie: że filozofia religii jest jedynie regionalną, jakkolwiek by ważną, gałęzią osadzoną na pniu metafizyki, łupiną, której jądrem jest filozofia bytu jako takiego. Jest tak dlatego po prostu, że Bóg jawi się pierwotnie jako najwyższa i w pewien sposób duchowa i osobowa Wartość — bynajmniej zresztą nie oderwana od bytu wartość Swiętości i pełnego mocy Dobra, która dana jest w doświadczeniu religijnym i która od razu domaga się od nas pewnej całościowej od powiedzi. Sposób tego dania jest, jak wiadomo, swoisty: zawsze poprzez różne - mówiąc językiem Jaspersa - szyfry, które w tej aksjologicznej i ontologicznej rzeczywistości jakoś uczestniczą. Lecz uczestniczą one tylko dla tego, kto sam jest w to uczestnictwo wplątany, kto czuje się przez tę świętość, będącą także pełnią bytu, osobiście zaapelowany i odnajduje jej obraz w głębi swego ja, splecionego nierozdzielnie z jakimiś ty. Innymi słowy ten tylko dostrzega Świę- 
tość, Najwyższe Dobro i Pełnię Bytu, kto się na nie w głębi swej osoby jakoś g o d zi, co pociąga za sobą implicite rezygnację z bycia centrum świata i poddanie się absolutnym wymogom, żądającym ode mnie uświęcenia w tej czy w innej postaci. Sposób zatem, w jaki Bóg się pierwotnie ,jawi”, tak iż można w ogóle o Nim w jakimkolwiek sensie mówić, wprowadza od razu dwa momenty:

1) poczucie, czy doświadczenie uczestnictwa w tym, co Marcel dobrze określa jako Tajemnicę, to znaczy w rzeczywistości, której najgłębszym sensem jawi się „żywy” Absolut, lecz która dlatego właśnie ma od razu sens dla m nie, staje mi się bliska, nieobojętna, a przez to niemożliwa do całkowitej obiektywizacji, jasna i niejasna zarazem.

2) moją wolność, a więc zgodę lub odmowę bycia zakwestionowanym i podporządkowania się pewnemu, rysującemu się przede mną projektowi sensu mo j e go ży ci a jako pewnej drogi dokądś, a nie donikąd. Tajemnica jawi się od razu jako pewien dramat, którego jestem współuczestnikiem, a nie widzem.

Tak więc pierwotnym „logosem” myśli o Bogu jest logos religijnej partycypacji, której najgłębszy sens wydaje się intersubiektywny i domaga się od strony ludzkiego podmiotu postawy wiary w szerokim tego słowa rozumieniu. Pociąga to za sobą postulat, w imię uczciwości intelektualnej, nawiązywania wszelkiej filozofii Boga do tych źródeł, a co najmniej świadomości, że metafizyka Boga domaga się korektury ze strony filozofii religii jako szczególnej, pierwotnej więzi - tak, jak zresztą filozofia religii domaga się włączenia w nią metafizycznego poziomu refleksji.

Marcelowska filozofia tajemnicy i wiary uczy także intelektualnej skromności, która nie jest agnostycyzmem. Gdyż tajemnica przypomina nam o tym, że ostatecznie ni e wi e m y tego, w co wierzymy i czego najgłębiej pragniemy, choć możemy doświ a d cza ć tego, czego nie sposób wypowiedzieć w sposób jasny i wyraźny.

Lecz z samej istoty takiej, jak Marcelowska, filozofii wypływa jej niedookreśloność, niejednoznaczność i aporetyczność. Wskażmy tu na trzy spośród zagadnień wyłaniających się z tej filozofii, będących również fundamentalnymi zagadnieniami filozofii Boga w ogóle.

\section{Zagadnienie granic możliwego do filozoficznej analizy doświadczenia Boga}

W filozofii Marcela znajduje się refleksyjny opis swoistego doświadczenia Boga, który tu po krótce przytoczmy.

Doświadczenie to przedłuża wprost pytanie o moje własne bycie, które wtrąca nas w odkrycie tajemnicy ontologicznej. Odkrycie to bowiem nie uśmierza, według Marcela, mego głodu wiedzy o tym kim naprawdę jeste m. Na to pytanie nie mogę jednak sobie ani odpowiedzieć sam, ani zaakceptować 
cudzej odpowiedzi, którą bym musiał i tak zweryfikować, albowiem kwestionuję tu siebie w całej rozciągłości, a więc podaję w wątpliwość możliwość udzielenia przez siebie jakiejkolwiek odpowiedzi. Skoro tak, to mogę tylko w e z w a ć kogoś, kto byłby moim absolutnym świadkiem i sędzią; „I może w tej mierze, w jakiej zdaję sobie sprawę z tego wezwania jako wezwania zmuszony jestem przyznać, że to wezwanie jest możliwe tylko dlatego, że w głębi mnie samego znajduje się coś innego niż ja sam, coś bardziej wewnętrznego niż ja sam - i tym samym wezwanie zmienia znak" (EA, 181). Lecz Marcel dodaje taki komentarz: „Można mi postawić zarzut, że wezwanie to może nie mieć rzeczywistego przedmiotu, że może w pewien sposób gubić się w ciemności. Ale coś ten zarzut oznacza? Że nie dotarła do mnie żadna odpowiedź na to pytanie, tzn. że ktoś inny nie odpowiedział. Pozostaję tutaj na płaszczyźnie stwierdzenia lub nie stwierdzenia; lecz wskutek tego zamykam się w kręgu tego, co problemowe [tzn. tego, co znajduje się przede mną]" (tamże).

Zagadnienie, które się tu rysuje, chciałbym najpierw sformułować następująco: jakie są granice doświadczenia religijnego, poza które filozofia jako taka nie powinna wykraczać? Inaczej mówiąc: czy „filozofia wiary” ma prawo być tylko refleksyjnym badaniem religijnych warunków możliwości pewnych „czysto ludzkich” mniej lub bardziej potocznych doświadczeń, pod pretekstem, że doświadczenia inne albo są ambiwalentne, albo wykraczają poza filozofię? Lecz, jak widać, ograniczenie takie prowadzi jedynie do pewnej wersji teologii negatywnej, która, jak się wydaje, nie oddaje sprawiedliwości pełnemu wachlarzowi doświadczeń religi n y ch: boskość czysto negatywna i, by tak rzec, postulatywna, nie interesowałaby nikogo. Ograniczenie pola operacji filozoficznej do takiej teologii negatywnej pomija możliwości kryjące się w doświadczeniu szeroko rozumianego o b j a w i e n i a religijnego, choćby takiego, jak objawienie się mocy laski u podstaw rozmaitego typu religijnych i moralnych nawróceń. Dopiero takie doświadczenia jednak wprowadzają nie tylko istotnie religijny moment dialogiczności relacji z Bogiem, lecz w pewnym sensie umożliwiają nam w ogóle kategorię doświadczenia religijnego. Ale, być może pranice między badaniami warunków możliwości doświadczeń potocznych, a badaniem doświadczeń religijnych sensu stricto są granicami między filozofią religi jną, a filozofią religii, których statusy metodologiczne należałoby w takim razie ściślej określić.

\section{Zagadnienie tego, co „wspólne” i tego, co „odrębne”}

Ta sama analiza warunków możliwości apelu do Absolutnego Świadka może zilustrować inne, kluczowe zagadnienie, jakie nasuwa Marcelowska filozofia religijna. Zagadnienie to ma dwie strony: w szerokim sensie epistemologiczną oraz ontologiczną. 
1. W cytowanym tekście Marcel wyciąga radykalne konsekwencje z idei tajemnicy: Absolutnego Ty nie można zi d en t y fi ko w ać, gdyż jest to operacja uprzedmiotowiająca; ale w ten sposób nie wiadomo również, czy partner dialogu istnieje i czy do nas naprawdę przemawia. Otóż jeśli ża d n a identyfikacja tego, co Boskie i jego odróżnienie od tego, co inne nie są możliwe, to z jednej strony nie ma różnicy między nieskończonością a nieokreślonością i Bóg może być równie dobrze mętnie odczuwaną całością rzeczywistości, w stopniu w jakim jest ona pewną jednością nie sprowadzalną do sumy części: $z$ drugiej strony identyfikacji tej domaga się chyba doświadczenie religijne jako takie, które jest bez wątpienia dialogiczne i nie jest wszak dla niego obojętne, czy mój apel zawisa w próżni, czy nie. Rodzą się tu więc następujące pytania: a) czy zastosowanie względem Boga zasady tożsamości jest w ogóle prawomocne?; b) jeśli jest prawomocne, to czy jest możliwe w filozofii tajemnicy, która jest, jak się zdaje, ontologiczną interpretacją doświadczenia mił ości rozumianej w perspektywie doświadczenia jedności?; c) jeśli identyfikacja dialogiczna jest mimo to możliwa, to czy nie wykracza ona — raz jeszcze — poza filozofię jako taką?

2. Od strony ontologicznej zagadnienie to prowadzi nas właśnie do marcelowskiej interpretacji intersubiektywnej jedności. W polemice z Buberem pisał Marcel: „Na początku... jest pewna odczuwana jedność, która staje się stopniowo uwyraźniona tak, że pozwala na wyłonienie się całości zawierającej wzajemnie do siebie odniesione terminy" (IT, 45). Istotą tej jedności jest doświadczenie intymności, w stosunku do której ja i ty wydajemy się abstraktami: „w łonie m y odrywam element nie-ja i nazywam go ty" (JM, 294).

Trzeba tu jednak zapytać o ostateczny s e n s tej jedności tam gdzie wchodzi $\mathrm{w}$ grę relacja diadyczna $\mathrm{z}$ Bogiem. $\mathrm{Z}$ jednej bowiem strony, podobnie jak między istnieniem a byciem — tak jak je rozumie Marcel — musi być podkreślona nie tylko jedność, lecz i różnica, tak również nasza dialogiczna i ontologiczna „jedność” z Bogiem — jedność partycypacji — nie może w żadnej mierze sugerować jakiejś całości: ostrość przeciwieństwa nieskończoności i skończoności musi zostać do końca wyraźnie utrzymana.

$\mathrm{Z}$ drugiej strony miłosna jedność ja i ty - a musi się to a fortiori stosować do naszej więzi z Bogiem - nie unieważnia, a właśnie poniekąd podkreśla różność. Jedność bowiem w miłości powstaje przecież przez to, że „jest się” całemu w drugim jako drugim, porzucając niejako siebie i przez to odnajdując. Dlatego musi budzić także wątpliwość zanotowana gdzieś uwaga Marcela, że gdyby Bóg nie był we mnie bardziej mną niż ja sam, to przekaz słowa Bożego przez konkretne Pismo mógłby zostać zinterpretowany jako „tyrański nakaz skierowany do mnie przez k ogoś poszcze góln e go, przeciwko któremu zrozumiałe jest, że się buntuję" (RI, 134). Zdanie to wydaje się sugerować, że gdyby boskie nie-ja było wyraźnie odrębne od ja, to alienowałoby owo ja. Ale dlaczego, jeśli tylko przez nie-ja, przez ty jako ty, a tym bardziej 
przez Absolutne Ty, jestem naprawdę sobą? Nie ma religii poza wyraźnym ruchem negacji skończoności i zarazem poza autentycznym dialogiem.

\section{Zagadnienie prawomocności u Marcela dyskursu filozoficznego na temat Boga ${ }^{2}$}

Od początku swego filozofowania Marcel stanął wobec konieczności usprawiedliwienia filozofii wobec religii i znalezienia dla niej miejsca.

Szczególnie drastycznie rysuje się ta sprawa w okresie wczesnym, w którym osiągnięcie poziomu religijnego jest równoznaczne $\mathrm{z}$ abdykacją z poziomu myśli pojęciowej w ogóle. Prowadzi to jednak Marcela do interesującej koncepcji nieuprzedmiotowiającego „myślenia $\mathrm{z}$ wnętrza wiary”. W dojrzałej filozofii Marcela myślenie to przybiera postać tzw. refleksji drugiej, pochylonej nad podmiotem partycypującym w tajemnicy i nad jego próbami, w których przebija się ku Transcendencji, a zarazem odzierającej z pretensji potoczno-obiektywistyczne myślenie, krystalizujące się w „refleksję pierwszą”.

Powstaje jednak u Marcela zasadnicza trudność. Ostatecznie bowiem filozofii wolno mówić u niego jedynie o doświadczeniach Boga jako niemożliwego do tematyzacji (w modus „on”), a tylko do przeżycia w modlitwie. Bóg jest Absolutnym Ty, co oznacza, że wolno mówić jedynie do Boga, a nie o Nim.

W pewnym sensie tak jest rzeczywiście: mówiąc o Bogu, mówimy o naszym, rozmaitego rodzaju, doświadczeniu Boga, w którym się nam jakoś objawia - ale „Boga nikt nigdy nie oglądał” i Jego istoty nie poznał. A przecież mamy potrzebę myślenia i mówienia o Bogu - i filozofia Marcela jest tego mimowolnym świadectwem — co najmniej z dwu powodów:

1. Objawienie Boga w łonie Tajemnicy „daje do myślenia”, a wiara poszukuje zrozumienia tego, co stało się jej udziałem. Myślenie próbuje zgłębić Boską Tajemnicę, która przyobiecuje ostateczne rozświetlenie mrocznej faktyczności egzystencji w świecie i wejście w pełne światło, które jest równocześnie zbawieniem. Napięcie między nieskończoną wartością objawienia a jego niejasnością wtrąca w wir pytań i pragnienie dojrzenia boskości w jej pełnej prawdzie. Możliwość odczytania prawdy w świetle pytań zakłada jednak podmiot nie tylko partycypujący, ale także na tyle wyosobniony i uwewnętrzniony, że może uzyskać dystans w stosunku do całej rzeczywistości, a przez to możliwość myślenia n a te m a t ... Możliwość ta jawi się podmiotowi zapytującemu zarazem jako nakaz odpowiedzialności za prawdę, która w wypadku Boga jawi się jako najbardziej radykalna. Z tego właśnie źródła, z odpowiedzialności za rozumną prawdę wypływają pytania i odpowiedzi na temat istoty $\mathrm{i}$ istnienia Boga, konstrukcje pewnych ontologicznych modeli Jego związków

${ }^{2}$ Pisałem na ten temat obszerniej w artykule: Uwagi o możliwości filozofii Boga, „Znak” 399: 1988 s. $3-18$. 
ze światem itd. Jakkolwiek nieadekwatne czy nawet fałszywe, są one mimo to niezbędne, wypływają bowiem z sytuacji człowieka zarazem ogarniętego objawieniem i poszukującego rozumnej prawdy.

2. Ale jest jeszcze i powód inny: imperatyw dawania św i a de ct wa o prawdzie objawienia. Charakter prawdy o Boskiej Tajemnicy powoduje, że adresuje się ona we wierze nie tylko do mnie osobiście wzywając mnie do konwersji i ostatecznie do świętości, lecz czyni mnie od razu odpowiedzialnym także za świadczenie o niej innym: prawda objawienia w sposób szczególny „świeci”, domaga się oddawania i szerzenia „chwały” Boga, jawnego głoszenia, że istnieje i jakim się jawi. Bóg religii jest zawsze Bogiem jakichś „braci”, do których jestem w pewien sposób „posłany”. Tak zatem Boska Tajemnica wzywa nie tylko do jej rozumienia, ale także do jej dalszego przekazywania, to zaś pociąga nieraz konieczność artykulacji pojęciowej. Swiadectwo - to przede wszystkim czyn miłości, ale to także słowo, a słowo religii jest ciężarne — jak mówi Tillich - potencjałem pojęciowym odsyłającym do jakiegoś wspólnego mimo wszystko doświadczenia, które trzeba móc wyłowić i móc mówić o Ty m, który się w nim ukazuje. Co więcej, filozofia religii będąc hermeneutyką doświadczenia religijnego zawiera także współczynnik myśli ściśle metafizycznej. Czy metafizyka ta ma charakter raczej obiektywistyczno-kosmologiczny czy raczej refleksyjno-duchowościowy, jest tu mniej ważne. Ma ona jednak w tej dziedzinie z pewnością prawo obywatelstwa, wraz z nieodłącznym od wszelkiej filozofii - w tym także filozofii religii sensu stricto - wymogiem ścisłości i możliwej jasności, lecz także pokory i nie żądania dla siebie monopolu.

Tak czy owak nie należy z perspektywy wiary nie doceniać „ewangelizacji przez rozum", do której wierzący czują się czasem wezwani, tak jak czują się nieraz zmuszeni do obrony — przy pomocy swego intelektualnego rynsztunku — własnej wiary wobec wiar innych. Tak bardzo dyskusyjny dla wielu termin „filozofia chrześcijańska” oznacza w każdym razie to właśnie: zaangażowanie z głębi własnego chrześcijaństwa w walkę o rozniecanie „trzeźwego upojenia” światłem prawdy w rozumnej duszy swej własnej i swego brata.

GABRIEL MARCEL ET LES PERSPECTIVES DE LA PHILOSOPHIE DE LA RELIGION

\section{Rés umé}

La situation de la religion dans le monde présent rend urgent, sur le plan intellectuel, la question de la philosophie religieuse qui montreraet ou s'entracine l'expérience religieuse, quelles sont ses conditions de possibilité et quel et le „logos” valable dans se domaine. La philosophie de Gabriel Marcel en est une des tentatives des plus promettenses. 
Dans la première partie de l'article il est question des structures fondamentales de cette philosophie qui ouvrent l'accès à la philosophie de la foi dont s'occupe la partie seconde. Il y est montré plusieurs étapes de cette philosophie de la foi liée à celle de la liberté humaine et qui débouche sur la philosophie de la conversion, du témoignage et du la fidélité comme crédit. Enfin on signale quelques difficultés de cette philosophie, entre autres celle des limites de la validité de l'expérience religieuse qui peut etre étudiée par cette philosophie, de l'identification de Dieu et de la possibilité du discours même sur Dieu. 